\title{
RADIO ECHO SOUNDING: BRINE PERCOLATION LAYER*
}

\section{By John W. Glough}

(Department of Geology and Geophysics, University of Wisconsin, Geophysical and Polar Research

Center, 6 I 18 University Avenue, Middleton, Wisconsin 53562, U.S.A.)

Abstract. An abrupt change in radio echo sounding travel time was observed on the ice shelf near McMurdo station, Antarctica, and was mapped by a zig-zag traverse. This boundary corresponds to the horizontal extent of brine penetration into the edge of the ice shelf.

RÉsumÉ. Sondage par echo radio: niveau de percolation d'eau salee. Un brusque changement dans le temps de parcours de l'écho-radio a été observé sur la plateforme de glace près de McMurdo station, dans l'Antarctique, et a été cartographié par un cheminement en zig-zag. Cette limite correspond à l'extension horizontale de la pénétration du sel sur la bordure de la plateforme.

Zusammenfassung. Radar-Echolotung: Eisschicht mit eingesickertem Salzwasser. Eine abrupte Änderung der Laufzeit bei der Radar-Echolotung wurde auf dem Schelfeis nahe der Station McMurdo, Antarctica, beobachtet und durch Messungen längs eines Zick-Zack-Kurses lokalisiert. Ihr Auftreten entspricht der horizontalen Ausdehnung des Eindringens von Salzwasser in den Rand des Schelfeises.

Smiтh and Evans (1972) consider reflections of radio waves from a layer of brine-soaked firn in their discussion of absorption by water inclusions. I would like to report on some measurements made on the ice shelf near McMurdo station (Clough and Bentley, 1967).

Profiling from the surface was carried out over $100 \mathrm{~km}$ of the grid system partially shown in Figure $\mathbf{I}$. Toward the western end of the shelf an abrupt change in apparent thickness was observed. On the

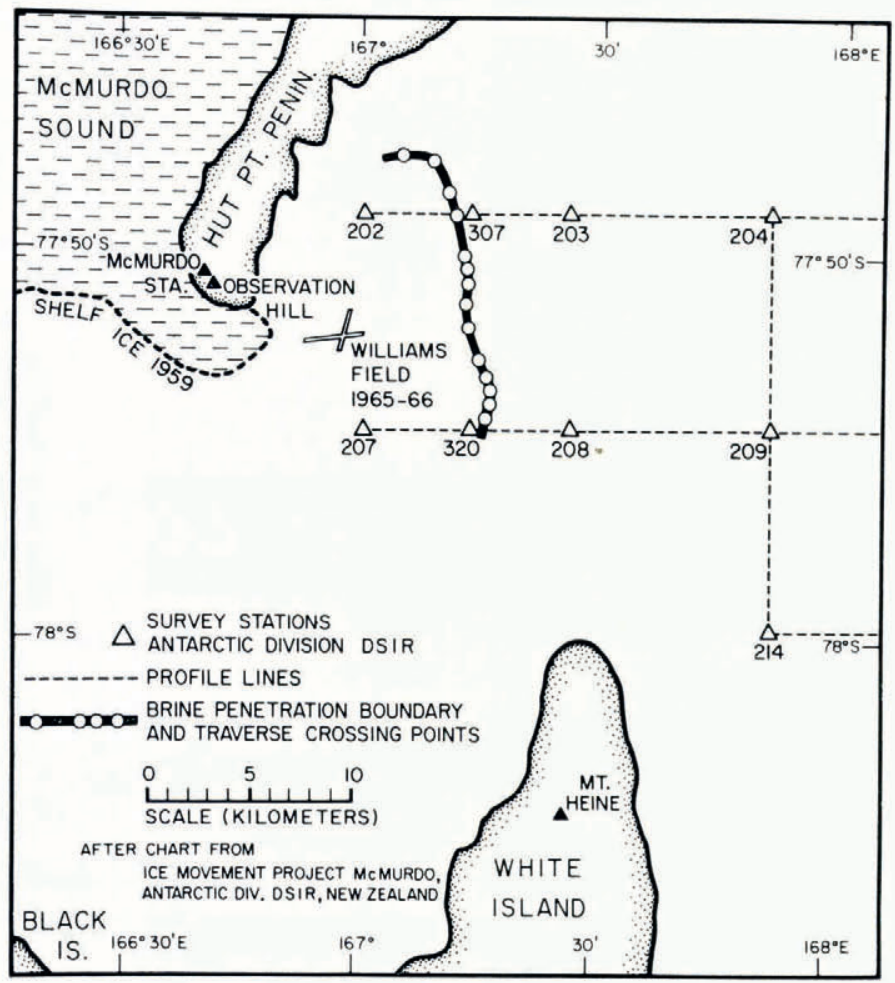

Fig. I. Area of survey on the ice shelf near McMurdo station, Ross Island.

* Contribution No. 287, Geophysical and Polar Research Center, University of Wisconsin. 
western side, the depth to the reflector was about 32-45 m compared with 95-120 $\mathrm{m}$ on the eastern side. The shallow reflector can be attributed to a brine penetration layer while the greater depth is consistent with the thickness of the ice shelf measured elsewhere.

Brine-soaked firn was found at a depth of $19 \mathrm{~m}$ in cores taken near station 207 (Heine, 1968), and at $26 \mathrm{~m}$ midway between stations 207 and 320 (personal communication from A. J. Heine in 1972). The eastern extent of brine penetration was found, by radio echo profiling, about $5.5 \mathrm{~km}$ east of 207 where the depth to the brine layer was about $32 \mathrm{~m}$. The depth corresponds well with Heine's estimate of $30-31 \mathrm{~m}$ at station 320 (personal communication from A. J. Heine in 1972). A portion of the boundary delineating the extent of brine penetration into the ice shelf was mapped by a zig-zag traverse. The boundary and traverse crossing points are shown in Figure I.

Reflection records obtained in the vicinity of the boundary are shown in Figure 2. The recorded echo changed completely from deep to shallow over distances of a few meters. Moving a few meters

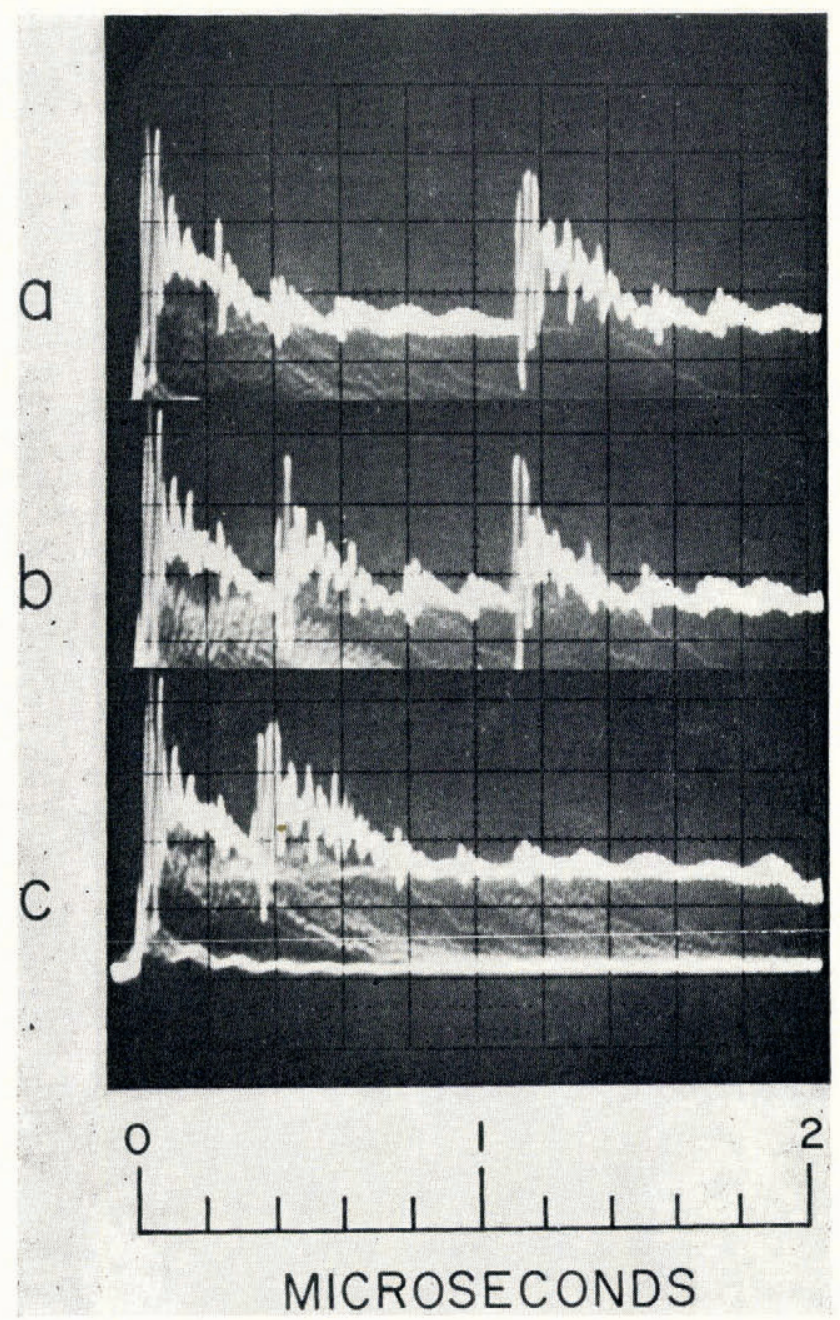

Fig. 2. Reflection records across the brine layer boundary.

a. Reflection from the bottom of the ice shelf is seen at approximately I.I $\mu$ s.

$b$. Reflection from both the bottom of the ice shelf and the top of the brine layer $(\approx 0.4 \mu s$.$) .$

c. Reflection from the top of the brine layer. The reflection from the bottom of the ice shelf is still visible but small. 
further to either side of the boundary normally resulted in extinction of the weak echo seen in Figure $2 \mathrm{a}$ or c. A very high reflection coefficient at the top of the brine layer and strong absorption within the layer result in no observed reflection from the bottom of the ice shelf in the region of the brine layer. The two echoes in Figure $2 \mathrm{~b}$ occur when both reflectors are "illuminated" by the transmitted wave, The time shift to the brine layer as seen in Figure $2 \mathrm{~b}$ and $\mathrm{c}$ may be due to the shape of the brine layer edge as well as to oblique incidence of the wave.

This research was supported by NSF Grant $\mathrm{GA}_{552}$.

MS. received 20 Fuly 1972

\section{REFERENCES}

Clough, J. W., and Bentley, C. R. 1967. Electromagnetic sounding of glacial and shelf ice. Antarctic fournal of the United States, Vol. 2, No. 4, p. I 19-20.

Heine, A. J. 1968. Brine in the McMurdo Ice Shelf, Antarctica. New Zealand Journal of Geology and Geophysics, Vol. II, No. 4, p. 829-39.

Smith, B. M. E., and Evans, S. 1972. Radio echo sounding: absorption and scattering by water inclusion and ice lenses. Fournal of Glaciology, Vol. 1 i, No. 6r, p. 133-46. 